\title{
PLASTINATION WITH SILICONE METHOD S 10 - MONITORING AND ANALYSIS CAUSES OF FAILURE
}

\author{
Mária Miklošováa, Vojtech Mikloš
}

\author{
${ }^{a}$ Department of Anatomy, Medical Faculty, University of P. I. Šafařik, Košice \\ ${ }^{b}$ Technical University, Košice, Slovak Republic \\ e-mail:Vojtech.Miklos@tuke.sk
}

Received: September 20, 2004

Key words: Plastination/Silicone S 10/Plastinated specimens/Shrinkage/Defects/Monitoring/Analysis

Plastination is in some cases unsuccessful. The goal of this work was to monitor, to describe and to analyse the reasons of S10 plastination method failure. We prepared the silicone-impregnated specimens using the standard silicone method S 10. The causes of bad preparation are numerous. Usual defects produced during plastination process are the changes in the bulk, the changes in the colour and other visible defects (e.g. deformations, spots on the organs surface). The frequent reasons for these defects are: unsuitable temperature, using of old bad fixed formaldehyde specimens and too long gas - curing procedure. The knowledge of reasons of unsuccessful plastination is important condition for achievement the good results.

\section{INTRODUCTION}

Plastination is method for long-term preserving of biological tissue. It is quite difficult to prepare well plastinated specimen. Unflexible specimen can be made also in case of keeping right technological procedure by preparing the specimens. Reasons of failure can be very miscellaneous. Many authors analysed the causes of plastination failure obtained by preparation of specimens ${ }^{1,2,6}$.

\section{MATERIALS AND METHODS}

\section{Preparing and plastination of specimens}

Plastination techniques (S 10) are essentially a vacuum process where all original tissue fluid are slowly extracted

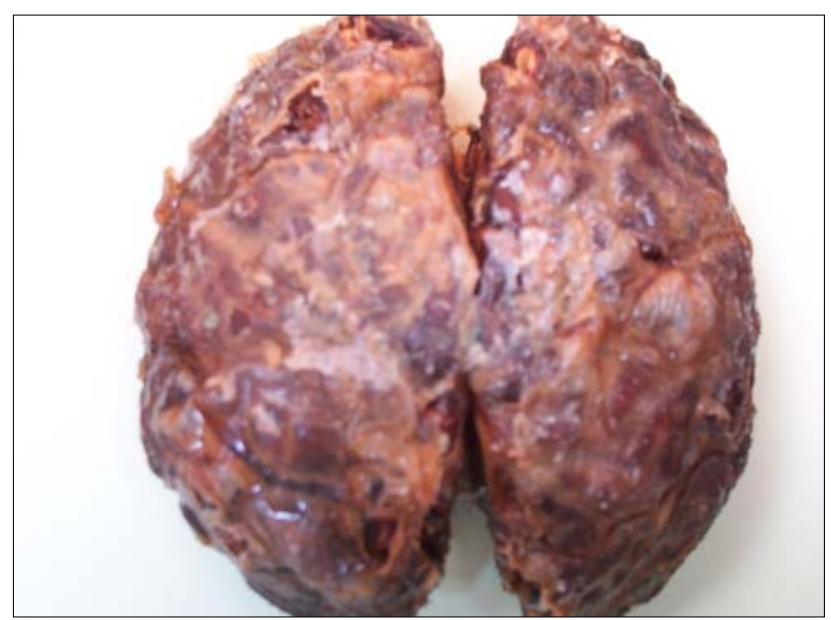

Fig. 1. Brain plastinated with silicone S 10 showing shrinkage and replaced by special curable polymer. By preparing of specimens was used standard silicone (S 10) method invented by Gunther von Hagens ${ }^{4}$, with application of polymers S 10, S 3 and S 6 (BIODUR ${ }^{\circledR}$ Germany). With this method has been prepared specimens of parenchymatous organs and organ complexes. All specimens for plastination were prepared by routine methods. Specimens were flushed with tap water, prepared and fixed with formalin. After fixation they were dehydrated in cold acetone $\left(-25^{\circ} \mathrm{C}\right)$ with three weekly changes. Acetone saved stabilisation of shape and caused only minimal shrinkage of tissue. The dehydrated specimens were impregnated at room temperature with a polymer reaction-mixture of S 10 and S 3 (100:1). The final vacuum ranged between 2 and $15 \mathrm{~mm} \mathrm{Hg}$. The process was completed after eight weeks impregnation. The specimens were drained of ex-

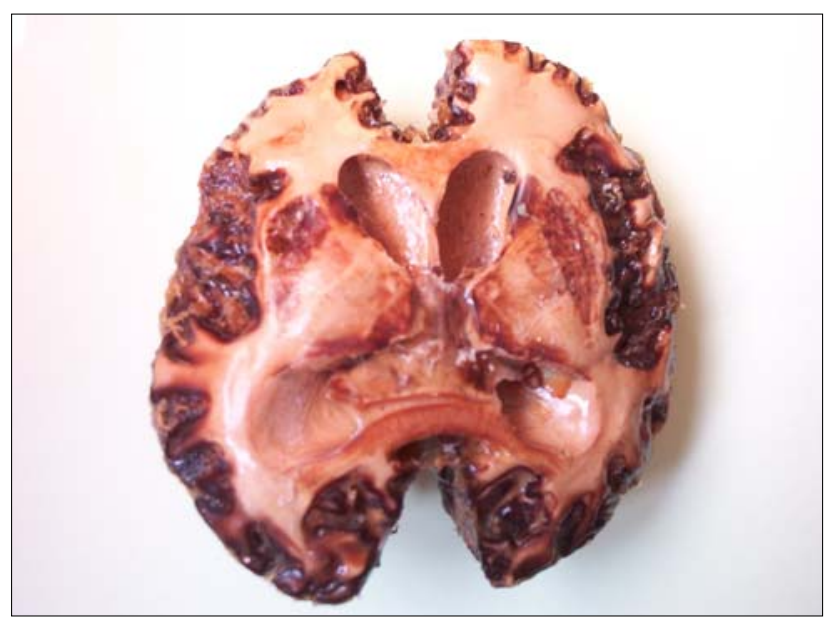

Fig. 2. Picture of S 10 plastinated horizontal brain slice with change of colour 


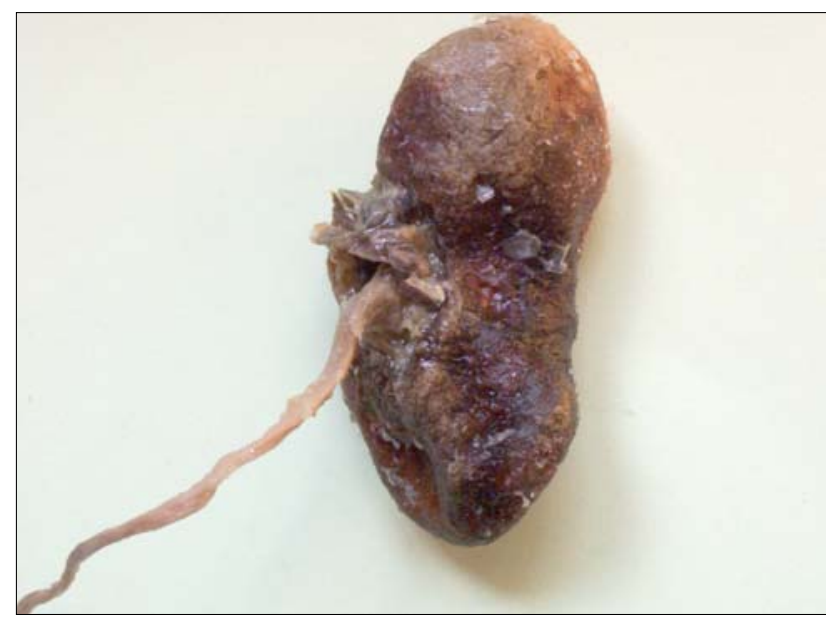

Fig. 3. Kidney. Plastinated with standard S 10 silicone method showing deformation

cess of polymer and hardened by exposure to S6 for two days. After hardening, the specimens were applicable in teaching process.

\section{RESULTS AND DISCUSSION}

The silicone S 10 technique is the standard technique and most frequently used method in plastination. There are lot of causes of failure by preparing of specimens. Most common failures are shrinkage (Fig. 1) and change of colour (Fig. 2) ${ }^{5}$. The other types of failures are visible defects, which includes deformation (Fig. 3), crained surface, damaged arteries and nerves or roughen surface of specimen ${ }^{7,8}$. The spots on organ surface are also common damage ${ }^{3}$, (Fig. 4). Based on our analyse, the causes of this defects are: inappropriate temperature of reaction mixture, usage of old formaline specimens with colour changes, usage of bad fixed specimens or the specimens with dry spots on surface testifying untimely drying of material. The menace of quality of specimen is also the long time of curing which causes lower flexibility. Last but not least cause of production of low quality specimens is their imprecise preparation.

To know the causes of unsuccessful plastination is important assumption to obtain the good results with this

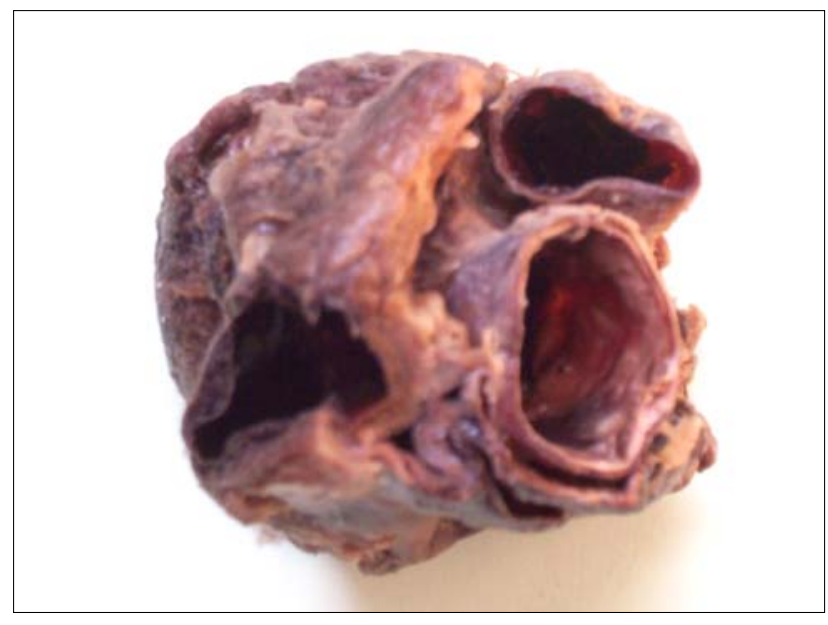

Fig. 4. Heart. Plastinated specimens with dark spots

method of conservation of biological tissue. An analysis of these causes can help the plastinators in their daily work.

\section{REFERENCES}

1 Bickley HC, Donner RS, Walker AR, Jackson RL. (1987) Preservation of tissue by silicone rubber impregnation. J Int Soc Plastination 1, 30-8.

2. Brown MA, Reed RB, Henry RW. (2002) Effects of dehydration mediums and temperature on total dehydration time and tissue shrinkage. J Int Soc Plastination 17, 28-33.

3. Gusnard D, Kirschner RH. (1977) Cell and organelle shrinkage during preparation for scanning electron microscopy: effects of fixation, dehydration and critical point drying. J Microscopy 110 (1), 51-7.

4. von Hagens G, Tiedemann K, Kriz W. (1987) The current potential of plastination. Anat Embryol 175, 411-21.

5. Latorre RM, Reed RB, Gil F, Azla MD, Martinez-Gomariz F, Henry RW. (2002) Epoxy impregnation without hardener: to decrease yellowing, to delay casting, andto aid bubble removal. J Int Soc Plastination 17, 17-22

6. Reed RB, Henry RW. (2002) Shrinkage assessment with classic plastination dehydrants. J Int Soc Plastination 17, 9-11.

7. Ripani M, Bassi A, Perracchio L, Perez M, Bocicia ML, Maranozzi G. (1994) Monitoring and enancement of fixation, dehydration, forced impregnation and cure in the standard S-10 technique. J Int Soc Plastination 8, 3-5.

8. Schwab K, von Hagens G. (1981) Freeze substitution of macroscopic specimens for plastination. Acta Anat 111, 139-40. 